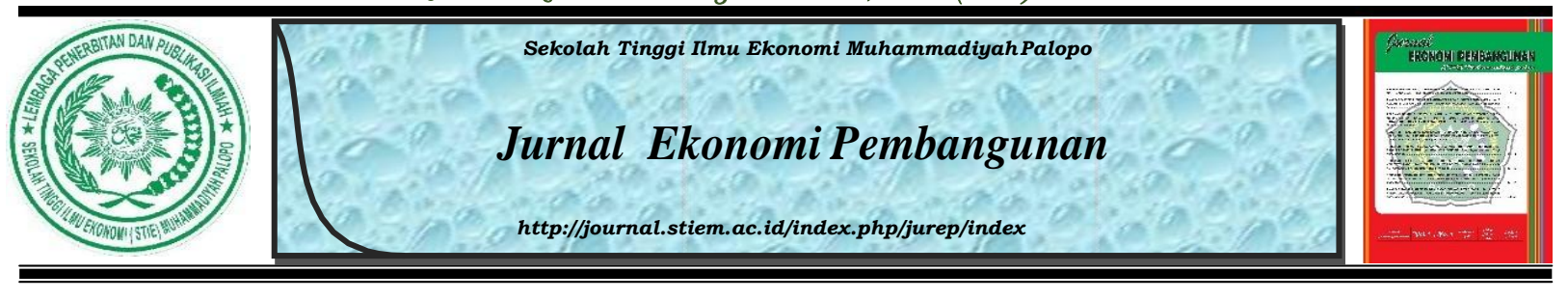

\title{
Pengaruh Tingkat Pendidikan Dan Jumlah \\ Penduduk Terhadap Tingkat Kemiskinan Di \\ Kabupaten Bone Tahun 2008-2017
}

St. Aminah

STIE Muhammadiyah Palopo

\section{INFO NASKAH}

Diserahkan

O2Mei 2019

Diterima

17 Mei 2019

Diterima dalam revisi

21 Mei 2019

Diterima dan disetujui

05 Juni 2019

\section{Kata Kunci:}

Tingkat Kemiskinan, Tingkat

Pendidikan dan Jumlah

Penduduk

\begin{abstract}
ABSTRAK
Penelitian ini bertujuan untuk mengetahui pengaruh tingkat pendidikan dan jumlah penduduk terhadap tingkat kemiskinan di Kabupaten Bone periode 2008-2017. Data yang digunakan dalam penelitian ini adalah data sekunder yang diperoleh dari Badan Pusat Statistik (BPS) Kabupaten Bone dan sumber lainnya sebagai pendukung. Metode yang digunakan adalah metode analisis berganda. Variabel terikat dalam penelitian ini adalah tingkat kemiskinan, sedangkan tingkat pendidikan dan jumlah penduduk sebagai variabel bebas. Teknik pengolahan data dalam penelitian ini menggunakan SPSS. Hasil analisis regresi menunjukkan bahwa tingkat pendidikan berpengaruh sigifikan terhadap tingkat Kemsiskinan di Kabupaten Bone dengan tingkat signifikan $0,19<0,05$ dan jumlah penduduk memiliki pengaruh yang signifikan terhadap tingkat kemiskinan di Kabupaten Bone dengan tingkat sigifikan $0,37<0,05$. Untuk uii $\mathrm{F}$ kedua variabel bebas secara bersama-sama (simultan) mempengaruhi variabel terikat (tingkat kemiskinan) dengan tingkat signifikan 0,40 $<0,05$.
\end{abstract}




\section{Pendahuluan}

Kemiskinan merupakan satu diantara persoalan mendasar yang menjadi pusat perhatian bagi pemerintah. Kemiskinan adalah kondisi dimana seseorang tidak dapat menikmati segala macam pilihan dan kesempatan dalam pemenuhan kebutuhannya. Hal ini dikarenakan kemiskinan bersifat multidensional, artinya karena kebutuhan manusia bermacammacam. Kemiskinan terus menjadi masalah fenomenal sepanjang sejarah, karena pemerintah belum memiliki strategi dan kebijakan pengentasan kemiskinan yang tepat. Kebijakan program penanggulangan kemiskinan yang di kembangkan sering kali kurang memperhatikan karakteristik dan konteks lokal masyarakat miskin. Untuk itu masalah kemiskinan dan pemberantasannya haruslah menjadi agenda wajib bagi pemerintah. Peran serta pekerja sosial dalam menangani permasalahan kemiskinan sangat diperlukan, terlebih dalam dalam memberikan masukan (input) dan melakukan perencanaan strategis tentang apa yang akan menjadi suatu kebijakan bagi pemerintah. Dalam menelaah kebijakan pemerintah dalam menanggulangi kemiskinan, perlu terlebih dahulu diperhatikan faktor yang mempengaruhi kemiskinan, sehingga program yang di buat pemerintah dalam menanggulangi kemiskinan di dasarkan pada faktor yang mempengaruhi kemiskinan. Kabupaten Bone adalah Kabupaten Bone adalah salah satu Kabupaten di pesisir timur Provinsi Sulawesi Selatan yang berjarak $174 \mathrm{~km}$ dari Kota Makassar yang memiliki posisi strategis dalam perdagangan barang dan jasa di Kawasan Timur Indonesia. Kabupaten Bone adalah Kabupaten terluas di Provinsi Sulawesi Selatan dengan jumlah Kecamatan sebanyak 27 Kecamatan. Tingkat Kemiskinan di Kabupaten Bone selama 10 (sepuluh) tahun terakhir dari tahun 2008-2010 mengalami penurunan dimana sejak tahun 2008 angka kemiskinan di Kabupaten Bone sebesar 17,35\% dan di tahun 2009 angka kemiskinan di Kabupaten Bone menurun sebebesar 15,19\% kemudian di tahun 2017 angka kemiskinan kembali menurun sebesar 10,28\% dari tahun-tahun sebelumnya. Berikut persentase tingkat kemiskinan di Kabupaten Bone selam 10 tahun terakhir. 
Persentase Tingkat Kemiskinan

Jurnal Ekonomi Pembangunan, (2019): 23-30

\section{Kabupaten Bone Tahun 2008-2017}

\begin{tabular}{|l|l|}
\hline \multicolumn{1}{|c|}{ Tahun } & \multicolumn{1}{c|}{$\begin{array}{c}\text { Tingkat } \\
\text { Kemiskinan (\%) }\end{array}$} \\
\hline 2008 & 17,35 \\
\hline 2009 & 15,19 \\
\hline 2010 & 14,08 \\
\hline 2011 & 12,67 \\
\hline 2012 & 12,25 \\
\hline 2013 & 11,92 \\
\hline 2014 & 10,88 \\
\hline 2015 & 10,12 \\
\hline 2016 & 10,07 \\
\hline 2017 & 10,28 \\
\hline
\end{tabular}

Sumber : BPS Kabupaten Bone

Salah satu faktor yang mempengaruhi tingkat kemiskinan adalah tingkat pendidikan. Tingkat pendidikan sebagai faktor terpenting yang dapat membuat seseorang keluar dari kemiskinan. Berdasarkan Survei Sosial Ekonomi Nasional Kor, Maret 2016 Kanupaten Bone Angka Partisipasi Murni (APM) tertinggi pada jenjang SD/MI dangan APM mencapai 97,97\% sedangkan Angka Partisipasi Kasar (APK) tertinggi berada pada jenjang SD/MI dengan APK 116,03\%. Selain Tingkat Pendidikan, kemiskinan juga terjadi karena diakibatkan oleh jumlah penduduk. Jumlah penduduk yang tinggi dan tidak diikuti dengan penyediaan lapangan kerja dan kualitas penduduk hal ini dapat menyebabkan angka kemiskinan akan meningkat. Penduduk Kabupaten Bone berdasarkan proyeksi penduduk tahun 2016 sebanyak 746.973 jiwa yang terdiri atas 356.691 jiwa laki-laki dan 390.282 jiwa penduduk perempuan. Kepadataan penduduk 27 kecamatan cukup beragam dengan kepadatan sebesar 2.193 jiwa dan terendah di kecamatan Bontocani sebesar 34 jiwa. 


\section{Metode Penelitian}

\subsection{Pendekatan Penelitian}

Penelitian ini menggunakan metode Kepustakaan sebagai metode pengambilan data, dan data yang mendukung diambil dari kantor Badan Pusat Statistik (BPS) Kabupaten Bone, jurnal, buku-buku dan observasi data di lokasi objek yang di teliti

\subsection{Populasi dan Sampel}

Populasi adalah jumlah keseluruhan dari unit atau obyek analisa yang ciri-ciri karakteristiknya hendak diduga. Populasi dan Sampel dalam penelitian ini adalah data time series Kabupaten Bone selama 10 tahun yaitu tahun 2008-2017

\subsection{Teknik Pengumpulan Data}

Untuk menjawab penelitian ini, peneliti menggunakan rumus yang sesuai dengan variabel yang melibatkan lebih dari satu variabel yang diteliti, yaitu rumus Regresi Linear Berganda yaitu sebagai berikut:

$\mathrm{Y}=\mathrm{a}+\mathrm{b}_{1} \mathrm{X}_{1}+\mathrm{b}_{2} \mathrm{X}_{2}+\mathrm{e}$

Keterangan:

Y : Tingkat Kemiskinan

$\mathrm{X}_{1}$ : Tingkat Pendidikan

$\mathrm{X}_{2}$ : Jumlah Penduduk

a : Konstanta

e : Nilai eror

b $(1,2, \ldots)$ : Koefisien Regresi

\section{Hasil dan Pembahasan}

\subsection{Hasil}

Berikut akan dibahas secara rinci mengenai hasil penelitian dari kedua variabel Tingkat Pendidikan (X1), dan Jumlah Penduduk (X2) terhadap Tingkat Kemiskinan di Kabupaten Bone sebagai berikut:

Analisis Regresi Linear Berganda dilakukan untuk mengetahui hasil yang diperoleh oleh kedua faktor yang berpengaruh terhadap Tingkat Kemiskinan Kabupaten Bone.

$\mathrm{Y}=\mathrm{a}+\mathrm{b} 1 \mathrm{X} 1+\mathrm{b} 2 \mathrm{X} 2$

$\mathrm{Y}=74,938+0,102 \mathrm{X} 1+0,535 \mathrm{X} 2$ 
Konstanta sebesar 74,938 yaitu Tingkat Pendidikan (X1), Jumlah Penduduk (X2) nilainya adalah 0, makan Tingkat Kemiskinan nilainya adalah 74,938 persen. Koefisien regresi variabel Tingkat Pendidikan (X1) sebesar 0,102 artinya setiap kenaikan tingkat pendidikan sebesar 1\%, maka Tingkat Kemiskinan (Y) akan mengalami penurunan sebesar 0,102 persen.

Koefisien variabel Jumlah Penduduk (X2) sebesar 0,535 artinya setiap kenaikan jumlah penduduk sebesar 1\%, maka Tingkat Kemiskinan (Y) akan mengalami peningkatan sebesar 0,535 persen.

\section{Analisis Korelasi Ganda (R) dan Determinasi (Adjust R Square)}

Diperoleh angka R (korelasi) sebesar 0,775 atau 77, 5 persen, hal ini menunjukkan bahwa terjadi hubungan yang sangat kuat antara variabel Tingkat Pendidikan ( $\left.\mathrm{X}_{1}\right)$ dan Jumlah Penduduk $\left(\mathrm{X}_{2}\right)$ terhadap Tingkat Kemiskinan (Y). Kemudian diperoleh $\mathrm{R}_{2}$ (determinasi) 0,601 atau 60,1 persen ini menunjukkan persentase sumbangan pengaruh variabel independen (tingkat pendidikan dan jumlah penduduk) terhadap variabel dependen (tingkat kemiskinan) atau dapat dikatakan bahwa variabel independen mampu menjelaskan sebesar 60,1 persen terhadap variabel Tingkat Kemiskinann dan sisanya 40,9 persen dijelaskan oleh variabel lain.

\section{Uji Parsial (Uji t) dan Uji Simultan (Uji F)}

Uji Simultan (Uji F) Diketahui Fhitung > Ftabel $(5,267$ > 4,373) ada pengaruh yang signifikan antara tingkat pendidikan dan jumlah penduduk terhadap tingkat kemiskinan di Kabupaten Bone. Uji Parsial (Uji t) Tingkat Pendidikan ( $\mathrm{X}_{1}$ ) terhadap Tingkat Kemiskinan (Y) yaitu thitung 3,042 > ttabel 1,895 maka variabel tingkat pendidikan berpengaruh signifikan terhadap tingkat kemiskinan di Kabupaten Bone. Jumlah Penduduk (X2) terhadap Tingkat Kemiskinan (Y) yaitu thitung 2,574 > tabel 1,895 maka variabel jumlah penduduk berpengaruh signifikan terhadap tingkat kemiskinan di Kabupaten Bone.

\subsection{Pembahasan}

a. Tingkat Pendidikan $\left(\mathrm{X}_{1}\right)$

Hasil pengujian statistik secara parsial yang telah dilakukan antara variabel tingkat pendidikan terhadap variabel tingkat kemiskinan dengan nilai signifikan sebesar 0,019 $<0,05$ atau di atas 5\% dan diperoleh hasil bahwa variabel tingkat pendidikan berpengaruh signifikan terhadap tingkat kemiskinan. Hal ini berarti jika tingkat pendidikan meningkat maka angka kemiskinan akan berkurang di Kabupaten Bone. 
Hal ini juga didukung teori Todaro 1994 yang mengatakan bahwa pendidikan merupakan cara untuk menyelamatkan diri dari kemiskinan. Semakin tinggi tingkat pendidikan, maka pengetahuan juga meningkat sehingga akan mendorong peningkatan produktivitas kerjanya. Semakin tinggi tingkat pendidikan, maka pengetahuan juga meningkat sehingga akan mendorong peningkatan produktivitas kerjanya. Penelitian ini sejalan dengan penelitian yang dilakukan oleh Fitri Amalia (2012) yang menyatakan bahwa pendidikan berpengaruh terhadap tingkat kemiskinan. Di dalam penelitiannya dia mengatakan pendidikan merupakan investasi yang imbalannya dapat diperoleh beberapa tahun kemudian dalam bentuk pertambahan hasil kerja dan mempengaruhi tingkat produktivitas. Penelitian ini juga sejalan dengan penelitian yang dilakukan oleh Priyo Adhi Nugroho (2015) yang menyatakan bahwa pendidikan memiliki pengaruh terhadap tingkat kemiskinan.

b. Jumlah Penduduk

Hasil pengujian statistik secara parsial yang telah dilakukan antara variabel jumlah penduduk terhadap variabel tingkat kemiskinan dengan nilai signifikan sebesar 0,037 $<0.05$ atau $5 \%$ dan diperoleh hasil bahwa variabel jumlah penduduk berpengaruh signifikan terhadap tingkat kemiskinan. Hal ini berarti berkurangnya jumlah penduduk dapat mengurangi tingkat kemiskinan. Penelitian ini juga didukung oleh teori Robert Malthus bahwa kecenderungan umum penduduk suatu negara untuk tumbuh menurut deret ukur yaitu 2 (dua) kali lipat setiap 30-40 tahun. Pertumbuhan penduduk yang tinggi dan penyebaran penduduk yang tidak seimbang akan mempengaruhi peningkatan kesejahteraan rakyat. Jadi baik itu jumlah penduduk bertambah atau berkurang tentu saja diperlukan usaha yang besar untuk mempertahankan kesejahteraan agar terhindar dari masalah kemiskinan. Penelitian ini sejalan dengan penelitian yang dilakukan oleh Candra Mustika (2011) yang menyatakan bahwa jumlah penduduk berpengaruh terhadap tingkat kemiskinan. Penelitian ini juga sejalan dengan penelitian yang dilakukan oleh Whisnu Adhi Saputra (2011) yang menyatakan bahwa jumlah penduduk memiliki pengaruh terhadap tingkat kemiskinan.

\section{Simpulan}

Berdasarkan pada hasil dan pembahasan dari penelitian yang diuraikan pada bab sebelumnya maka ditarik kesimpulan sebagai berikut:

a. Terdapat pengaruh yang signifikan antara variabel tingkat pendidikan 
terhadap variabel tingkat kemiskinan di Kabupaten Bone. Hal ini berarti semakin tinggi tingkat pendidikan maka semakin berkurang tingkat kemiskinan di Kabupaten Bone.

b. Terdapat pengaruh yang signifikan antara variabel jumlah penduduk terhadap variabel tingkat kemiskinan di Kabupaten Bone. Hal ini berarti berkurangnya jumlah penduduk akan mengurangi tingkat kemiskinan di Kabupaten Bone.

c. Secara simultan (bersama-sama) terdapat pengaruh signifikan antara variabel tingkat pendidikan dan jumlah penduduk terhadap tingkat kemiskinan di Kabupaten Bone. 


\section{Daftar Pustaka}

Amalia, Fitria. 2012. Pengaruh Pendidikan, Pengangguran dan Inflasi terhadap Tingkat Kemiskinan di Kawasan Timur Indonesia (KTI) periode 2001-2010. EconoSains. Vol: X, No: 2. (di akses tanggal 1 maret 2018).

BPS. 2017. Indikator Kesejahteraan Rakyat Kabupaten Bone 2016. Bone.

Nugroho, Adi, Priyo. 2015. Pengaruh PDRB, tingkat Pendidikan dan Pengangguran terhadap kemiskinan di Kota Yogyakarta tahun 1999-2013. Skripsi. Yogyakarta: Gelar sarjana Pendidikan.

Malthus, Robert. 2007. Kependudukan Dilema dan Solusi. Bandung: Nuansa.

Mustika, Candra. 2011. Pengaruh PDB dan Jumlah Penduduk terhadap Kemiskinan di Indonesia periode 1990-2008. Jurnal Paradigma Ekonomika. Vol: 4, No: 4. Universitas Jambi, Kampus Pinang Masak. (di akses tanggal 27 februari 2018).

Saputra. Adhi, whisnu. 2011. Analisis Pengaruh PDRB, IPM, Pengangguran terhadap Tingkat Kemiskinan di Kabupaten/Kota Jawa Tengah. Fakultas Ekonomi Unuversitas di Ponegoro. (11 januari 2018). (di akses tanggal 11 januari 2018).

Todaro. 1994. Pembangunan Ekonomi. Jakarta: Erlangga. 